\title{
COMMENTS
}

\section{UNDOING A LESSON OF FEAR IN THE CLASSROOM: THE LEGAL RECOURSE OF AIDS-LINKED GHILDREN}

\author{
LISA J. SoTTO†
}

\begin{abstract}
AIDS, implacable and thus far incurable, comes as a shock. It arrives like a cannibal at the picnic and calmly starts eating the children. -Morrow, Plague Mentality.*
\end{abstract}

This statement ${ }^{1}$ characterizes the "epidemic of fear" we are presently experiencing as a result of the recent dramatic rise in cases of acquired immunodeficiency syndrome, more commonly known as AIDS. ${ }^{2}$ The American public has attached to this disease a stigma ${ }^{3}$ far worse than that which the medical community believes is justified. Although medical experts have claimed "with assurance" that AIDS is "an extremely difficult disease to catch" and is not transmitted by casual contact, a recent poll shows that more than one half of the American public believes otherwise. ${ }^{.}$Indeed, this Comment maintains that it

† B.A. 1984, Cornell University, College of Arts and Sciences; J.D. Candidate 1987, University of Pennsylvania.

* Morrow, The Start of a Plague Mentality, Time, Sept. 23, 1985, at 92.

1 Id.

2 See Adler, The AIDS Conflict, Newswezk, Sept. 23, 1985, at 18. The media and others have played major roles in fueling fears about AIDS by referring to AIDS as "the Black Death of the 20th century," National Democratic Policy Committee, Memorial Bill for Emergency Measures to Deal with the Growing AIDS Epidemic 1 (1985) (on file with the University of Pennsylvania Law Review), and by calling its victims "lepers," Thomas, The New Untouchables, TIME, Sept. 23, 1985, at 24. See also LIFE, July 1985, at coverpage ("Now No One is Safe from AIDS").

3 This stigma is evidenced by the unprecedented attention that the media recently has given to AIDS. See, e.g., Adler, supra note 2, at 18; Thomas, supra note 2, at 24.

4 N.Y. Times, Sept. 20, 1985, at A15, col. 4 (quoting Dr. James O. Mason, Director, Centers for Disease Control).

See N.Y. Times, Sept. 12, 1985, at B11, col. 3. A New York Times/CBS poll found that $51 \%$ of the participants believed that AIDS was one of the two or three "most serious medical problems facing the country," although almost all of those polled 
is the fear of AIDS, rather than AIDS itself, which gnaws at the flesh of the children.

This overwhelming fear, based primarily on misinformation and ignorance of medical data, has created a class of people considered to be "[t]he [n]ew [u]ntouchables." Many individuals who are suffering from AIDS or an AIDS-related condition, who are related to an AIDS patient, or who are members of high-risk groups for contracting AIDS, experience groundless discrimination, isolation, and ostracism. ${ }^{7}$ Such discrimination is manifested prominently in the current controversy concerning the decision of several local school boards to exclude from the regular classroom children who either have been diagnosed or are perceived as having AIDS. ${ }^{8}$ These exclusions are unwarranted because they are based on irrational fears. The weight of available medical evidence clearly demonstrates that AIDS is transmissible only through acts that would not occur in the normal school setting.

This Comment argues that children facing AIDS-related discrimination are protected by several federal laws that prohibit discrimination against disabled individuals, as well as by the equal protection clause of the fourteenth amendment to the Constitution. ${ }^{9}$ Each of these enactments prohibits school officials from segregating or excluding an AIDSlinked child from the regular classroom. ${ }^{10}$ The discussion will proceed

claimed to be aware of the very limited number of ways in which AIDS could be transmitted. See id.

- Thomas, supra note 2, at 24.

7 For example, the New York City Commission on Human Rights received 288 reports of AIDS-related discrimination between July 1, 1984 and June 30, 1985. See Commission on Human Rights, New York City Commission on Human Rights Gay and Lesbian Discrimination Documentation Project (1985 update) (unpublished manuscript) (on file with the University of Pennsylvania Law Review).

${ }_{8}$ A four-year-old child with an AIDS-related condition was barred from the classroom in Washington Borough, New Jersey, along with her healthy nine-year-old brother, see Thomas, supra note 2, at 25; infected triplets were excluded from the regular public school in Dade County, Florida, see N.Y. Times, Sept. 8, 1985, at A1, col. 1; a 13-year-old hemophiliac with AIDS was excluded from school in Kokomo, Indiana, see McGrath, The AIDS Issue Hits the Schools, TIME, Sept. 9, 1985, at 61; three children in New York City were removed from their classrooms by community school board superintendents because of suspicions that the students' mothers' boyfriends were infected, see N.Y. Times, Oct. 4, 1985, at B1, col. 4.

- U.S. Const. amend. XIV, § 1 . The federal statutes to be discussed are the Rehabilitation Act of 1973, 29 U.S.C. $\$ \S 701-796(i)$ (1982 \& Supp. III 1985 \& West 1986), and the Education of the Handicapped Act, 20 U.S.C. $\S \S 1400-1454$ (1982 \& Supp. III 1985). The latter statute is also known as the Education for All Handicapped Children Act because "that was the official name of the 1975 statute which extensively amended and expanded the EHA." Goodwin, Public School Integration of Children with Handicaps After Smith v. Robinson: "Separate But Equal" Revisited?, $37 \mathrm{ME}$. L. REv. 267, 271 n.25 (1985).

10 Future references to "AIDS-linked children" and "AIDS-related children" will include: (1) children who have been diagnosed as having AIDS; (2) children with 
on the following assumptions: first, that the AIDS-linked children at issue are physically capable of withstanding a normal school day; second, that such children have no unusual behavioral problems, are in complete control of their bodily secretions, and do not have uncoverable, oozing skin lesions; and third, that medical experts will continue to regard AIDS as posing no danger to other students in the normal classroom setting.

\section{Medical Background of AIDS}

AIDS is a physical disorder that destroys the body's ability to fight certain infectious diseases. ${ }^{11}$ The virus believed to be responsible for causing AIDS is human T-lymphotropic virus type-III, known as HTLV-III. ${ }^{12}$ Current reports estimate that of the 1.5 million people thought to be infected with the HTLV-III virus, at least fifty percent will eventually develop AIDS. ${ }^{13}$ Other conditions, collectively referred to as AIDS-related complex (ARC), are also caused by infection from the HTLV-III virus but do not necessarily result in AIDS. Some individuals with ARC will eventually develop opportunistic infections that the national Centers for Disease Control (CDC) defines as AIDS and will be classified as AIDS patients. ${ }^{14}$ There is no cure for AIDS and no

AIDS-related conditions, see infra text accompanying note 14 ; (3) children who have tested positively for the HTLV-III virus, the virus associated with the disease, but who show no symptoms of AIDS and may never contract it; and 4) children who are in a high-risk group or who have family members in a high-risk group for contracting AIDS. Because all of these children face similar forms of discrimination, and because medical evidence indicates that none of these children can transmit AIDS in the normal school setting, this Comment generally will not distinguish among them for purposes of discussing their legal options. In certain sections of this Comment, however, it may be necessary to distinguish between children diagnosed as having AIDS and children merely perceived as having AIDS.

II See New York City Dep't of Health, AIDS: A Special Report on ACQUIRED IMMUNODEFICIENCY SYNDROME 1, 3 (Oct. 1985) [hereinafter AIDS: A SPECIAL REPORT]. An AIDS patient is susceptible to certain opportunistic infections such as Kaposi's sarcoma, a type of cancer; pneumocystic carinii pneumonia; and certain fungal infections. See Indiana State Bd. of Health, Guidelines for Children with AIDS/ARC Attending School 1 (July 1985) (on file with the University of Pennsylvania Law Review); AIDS: A SPECIAL RePORT, supra, at 3.

12 See New York City Dep't of Health, Aids: New York City Update, 4 CITY Health Information 1, 2 (July 24-31, 1985) (hereinafter AIDS: New York City Update]. The HTLV-III virus is also known as LAV, Lymphocyte Associated Virus, referring to the name that French scientists assigned to the virus.

is See Wallis, You Haven't Heard Anything Yet, TIME, Feb. 16, 1987, at 54; See also Smilgis, The Big Chill: Fear of AIDS, TIME, Feb. 16, 1987, at 50,51 (more than $90 \%$ of those thought to be infected with the AIDS virus do not know that they are carriers; additionally, the incubation period for the virus may be as long as 10 years).

Most statistics used in this Comment represent current figures at the time the piece went to press; however statistics constantly are being updated.

14 See AIDS: New York City Update, supra note 12, at 2. 
preventive vaccine. Government experts predict that a vaccine or therapy to limit the spread of the disease will not be available before $1990 .{ }^{18}$ The only present possibility for treatment "is to treat intensively each infection as it arises and when that particular infection has been eradicated, return the patient to the milieu in which he lives."16

In 1981, AIDS was first identified under the name by which it is presently known. ${ }^{17}$ Since that time, more than 30,000 cases resulting in more than 15,000 deaths have been reported nationwide. ${ }^{18}$ More than 200 cases of juvenile AIDS have been diagnosed, ${ }^{\mathbf{1 0}}$ and it is reported that there is a sixty-nine percent mortality rate for children. ${ }^{20}$ The two groups at highest risk for contracting AIDS are homosexual or bisexual men, and male or female intravenous drug users. Together, these groups account for approximately ninety-three percent of AIDS cases in the United States. ${ }^{21}$ Other risk groups include sexual partners of individuals at risk for AIDS, infants born to parents at risk for AIDS, and people who received transfusions of blood or blood products prior to the development of the HTLV-III antibody test now used to assure that all blood donated for use is free from the HTLV-III virus. ${ }^{22}$ The majority of children with AIDS received the disease from their infected mothers, either during pregnancy or during the birth process. ${ }^{23}$ Blood transfusions administered before the use of the HTLV-III antibody test

${ }^{16}$ See N.Y. Times, Dec. 24, 1985, at C1, col. 6.

16 Johnson, Editorial, 52 Medico-LeGAL J. 3 (1984).

17 See Centers for Disease Control, Update: Acquired Immunodeficiency Syndrome (AIDS)_United States, 32 Morbidity \& Mortality WeEkLy Rep. 688 (1984).

${ }^{18}$ See Wallis, supra note 13 , at 54.

19 See Center for Infectious Diseases, Genters for Disease Control,

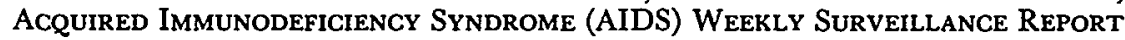
- UNIted States AIDS Activity 1 (Sept. 16, 1985) [hereinafter WeEkly SuRveilLANCE REPORT]; N.Y. Times, Oct. 24, 1985, at A19, col. 1.

20 See Washington Post, May 10, 1985, at A13, col. 1.

21 See WEEkLY SURVEILlANCE REPORT, supra note 19, at 2.

22 See AIDS: New York City Update, supra note 12, at 3. The HTLV-III antibody test can determine whether a person has developed antibodies to the virus, indicating probable exposure to HTLV-III. A positive reaction to the test indicates that the individual may be immune to the infection after having conquered it, may be carrying the infection but showing no symptoms, or may be diagnosed as an AIDS victim. This test is not an adequate predictor of AIDS, especially since AIDS will develop in only a small minority of persons infected with the HTLV-III virus. See AIDS: A SPEcial REPORT, supra note 11, at 14-17.

23 The mothers of children infected in utero with HTLV-III are generally women with a history of intravenous drug use or women who have had sexual partners who were either intravenous drug users or bisexual men. See AIDS: New York City Update, supra note 12, at 3 . Ingestion of an infected mother's breast milk also has been cited as a possible source of infection. See N.Y. Times, Sept. 13, 1985, at B3, col. 1 (offering answers from medical authorities to questions concerning transmission of the AIDS virus). 
have also caused AIDS in a number of juvenile victims. ${ }^{24}$ In addition, children, like adults, may acquire the disease through use of intravenous drugs or sexual contact with an infected partner.

Thus, AIDS has been transmitted in three ways: through sexual contact, through injection of a substantial amount of infected blood directly into an individual's body, and through infection from mother to child in utero or during the birth process. ${ }^{25}$ Although the HTLV-III virus has been detected in saliva and tears, there are no documented cases of AIDS resulting from transmission by these bodily fluids. ${ }^{26}$ Health experts contend that "transmission through ordinary social contact is virtually impossible." 27 None of the identified AIDS cases in the United States is known to have been transmitted through casual contact between individuals. ${ }^{28}$ AIDS is not spread by any airborne method, such as coughing or sneezing, nor is it transmitted by sharing food, water, or eating utensils with infected persons. ${ }^{29}$

In studies of children afflicted with AIDS who were monitored for periods of a few months to five years, no other member of any child's family acquired either AIDS or the HTLV-III virus as a result of contact with the infected child. ${ }^{30}$ These children shared drinking cups, beds, and even toothbrushes with their siblings; nevertheless, the siblings remained healthy. ${ }^{31}$ In fact, some families took no special precau-

24 Blood banks and hospitals began using the HTLV-III antibody test in March 1985. See Centers for Disease Control, Education and Foster Care of Children Infected with Human T-Lymphotropic Virus Type III/Lymphadenopathy-Associated Virus, 34 Morbidity \& MORTALITY WeEkLy ReP. 517, 518 (August 30, 1985) [hereinafter Education and Foster Care of Children]; Washington Post, May 10, 1985, at A13, col. 1.

${ }_{28}$ It should be noted that "[s]trong evidence indicates that large quantities of such infected materials as blood or sexual discharges must enter the body to spread the disease." N.Y. Times, Sept. 13, 1985, at B3, col. 1.

${ }^{26}$ See Education and Foster Care of Children, supra note 24, at 518. The presence of HTLV-III is extremely rare in saliva and there is no evidence that the virus is transmitted through saliva. See District 27 Community Bd. v. Board of Educ., 130 Misc. 2d 398, 407 \& n.3, 502 N.Y.S.2d 325, 331-32 \& n.9 (Sup. Ct. 1986) (citation omitted); N.Y. Times, Sept. 13, 1985, at B3, col. 1. HTLV-III is not present in perspiration, urine, or feces. See id.

27 N.Y. Times, Oct. 24, 1985, at A19, col. 1 (discussing recommendations of the American Academy of Pediatrics).

28 See Education and Foster Care of Children, supra note 24, at 519.

${ }^{29}$ See N.Y. Times, Sept. 13, 1985, at B3, col. 1.

so See Department of Health, State of New York, Public Health Se-

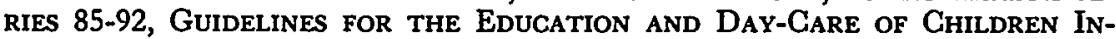
FECTED WITH HUMAN T-LyMPHOTROPIC VIRUS TYPE III/LYMPHOADENOPATHYAssociated Virus (HTLV III/LAV) 2 (September 4, 1985); N.Y. Times, Sept. 20, 1985 , at A15, col. 4.

${ }^{31}$ See N.Y. Times, Sept. 20, 1985, at A15, col. 4. "[N]ot one family member of the more than 13,000 victims reported to the Federal Centers for Disease Control has become infected with the virus, despite what in many cases was [sic] years of close 
tions against contracting the disease because it was not known for many years that a child in the family had AIDS. Even so, there is no evidence that the healthy siblings of these children were infected with the HTLV-III virus as a result of contact with their infected family members. It seems clear, then, that while a theoretical risk of transmission from casual contact remains a remote possibility, such transmission is virtually impossible as a practical matter. Indeed, the director of the GDC has stated that the risk of contracting AIDS from a child in the classroom is comparable to that of " being struck by lightning when you walk out the front door in the morning," " and the risk of getting the disease as a result of the casual contact that occurs in a school setting is "much less than the chance of the boiler that heats the building blowing up." "s2

\section{Federal Enactments that Prohibit Discrimination Against AIDS-Linked GHILDREN}

Because the risk of contagion by the type of casual contact that occurs in a school setting is "nil or infinitesimally small,"33 any attempt to exclude or segregate AIDS-linked children from the regular classroom is unwarranted and therefore constitutes unlawful discrimination. Although the AIDS "epidemic" 34 raises a reasonable health concern in many circumstances, the fear some parents and school administrators have displayed with regard to the presence of AIDS-linked children in regular schools is unfounded. ${ }^{35}$

contact with an infected person ... ."N.Y. Times, Sept. 13, 1985, at B3, col. 1.

${ }^{32}$ N.Y. Times, Sept. 12, 1985, at B11, col. 3 (quoting Dr. James O. Mason, Director, GDC). Dr. Pauline Thomas, a pediatric AIDS specialist with two young children, was asked under oath whether she would allow one of her children to be given the HTLV-III antibody test if the child had been bitten by a known AIDS patient. The doctor quickly and unequivocally replied that she would not. See N.Y. Times, Sept. 23, 1985, at B5, col. 1; see also N.Y. Times, June 20, 1986, at A14, col. 1 (reporting that the American Medical Association recommends that AIDS-linked children not be barred from public schools).

ss Boston Globe, May 12, 1985, at 29, col. 5, 36, col. 3.

34 Federal authorities have explained that AIDS is considered an epidemic because of the unexpected increase in its incidence, not because it is easily transmissible. See N.Y. Times, Sept. 13, 1985, at B3, col. 1.

so Parental concern for the health and well-being of schoolchildren is certainly understandable. Such fear, however, should not be permitted to interfere with proper decisionmaking. As one New York court has stated:

Although this court certainly empathizes with the fears and concerns of parents for the health and welfare of their children within the school setting, at the same time it is duty bound to objectively evaluate the issue of automatic exclusion according to the evidence gathered and not be influenced by unsubstantiated fears of catastrophe.

District 27 Community School Bd. v. Board of Educ., 130 Misc. 2d 398, 413, 502 
In other contexts, such fear has failed to justify the exclusion of AIDS victims. In LaRocca $v$. Dahlsheim, ${ }^{36}$ for example, healthy prisoners sought to expel infected prisoners from the same correctional facility. After reviewing the medical data, the court held that removing AIDS-linked prisoners from the facility was wholly unwarranted. ${ }^{37} \mathrm{Be}$ cause the conditions of interaction among students in the classroom are much less confined than those among incarcerated prisoners, the result in LaRocca clearly argues against segregating AIDS-linked children from the regular schoolroom.

Nevertheless, several school administrators and school boards have attempted to bar AIDS-related children from unrestricted learning in their normal classrooms. ${ }^{38}$ One such resolution passed by a community school board in Queens, New York, stated that because

the health and safety of the pupil/staff population of the thirty-five schools under its jurisdiction would be endangered by a case, contact or carrier, or suspected case, contact or carrier of AIDS . . . said child(ren) shall not be admitted to any school register and/or shall be removed from any school register ${ }^{39}$

in that school district. This resolution would bar from the classroom any child diagnosed as having AIDS; any child who has tested positively for the HTLV-III virus; any child with ARC; and any child who has a relative with AIDS, is a member of a high-risk group for contracting AIDS, or has a friend or relative who is a member of such a high-risk group. ${ }^{40}$

The federal enactments that could protect AIDS-linked children from these and other discriminatory regulations are section 504 of the

N.Y.2d 325, 335 (Sup. Ct. 1986) (citation omitted); see also Note, The Constitutional Rights of AIDS Carriers, 99 HARv. L. REv. 1274, 1291 (1986) ("Although even the most rational parents may feel uneasy knowing their children attend school with an AIDS carrier, it is the real, not the perceived, health hazard that courts must consider.").

${ }^{38} 120$ Misc. 2d 697, 467 N.Y.S.2d 302 (Sup. Ct. 1983).

s7 Id. at $709-10,467$ N.Y.S.2d at 310-11.

38 See supra note 8 and accompanying text.

38 Community School Board-District 27, City of New York, Addendum to the Community School Board 27 Open Meeting Agenda of August 22, 1985 (on file with the University of Pennsylvania Law Review) [hereinafter Addendum]. The school board asserted that "a conservative attitude toward the care and teaching of our children is the most sensible and responsible approach." Id.

10 Community school boards in districts 27 and 29 voted to prohibit any child with AIDS or any child perceived as having AIDS from attending their normal schools. Although the school boards sought an injunction to prevent such children from attending regular classes, see N.Y. Times, Sept. 10, 1985, at B1, col 2, B5, col. 1, a state trial court denied their request. See District 27 Community School Bd. v. Board of Educ., 130 Misc. 2d 398, 422-23, 502 N.Y.S.2d 325, 341-42 (Sup. Ct. 1986). 
Rehabilitation Act of $1973,{ }^{41}$ which prohibits discrimination against the disabled; the Education of the Handicapped Act, ${ }^{42}$ which evidences a strong federal policy favoring full education for the handicapped; and the equal protection clause of the fourteenth amendment. ${ }^{43}$ Each will be discussed in turn.4

\section{A. The Rehabilitation Act of 1973}

The Rehabilitation Act of 1973 [the Act] provides a legal basis on which AIDS-linked children may assert a right to a regular, nonsegregated education. Section 504 of the Act mandates: "No otherwise qualified handicapped individual in the United States . . . shall, solely by reason of his handicap, be excluded from the participation in, be denied the benefits of, or be subjected to discrimination under any program or activity receiving Federal financial assistance."45 Since public schools in all states but one utilize federal funds for their educational programs, ${ }^{46}$ federal law prohibits these schools from discriminating against handicapped schoolchildren.

The Rehabilitation Act defines a "handicapped individual" as "any person who (i) has a physical . . . impairment which substantially limits one or more of such person's major life activities, (ii) has a record of such impairment, or (iii) is regarded as having such an impairment." 47 The Act's coverage of "otherwise qualified handicapped individual[s]" means that a person suffering from a disability may not be treated differently from a nondisabled individual. Furthermore, the Act includes within its scope persons who presently have no incapacity at all, or who have a disability that does not substantially limit major life activities, but who are merely perceived as having an impairment that substantially limits such activities. ${ }^{48}$ The Act's language and the

1129 U.S.C. \& 794 (1982 \& Supp. III 1985).

1220 U.S.C. $\S \S 1400-54$ (1982 \& Supp. III 1985).

43 U.S. ConsT. amend. XIV, $\S 1$.

44 This Comment does not treat as distinguishable children diagnosed as having AIDS and children merely perceived as having AIDS. These two groups of children are indistinguishable with respect to the issues presented herein because it is assumed that no child in either group can transmit AIDS in the typical school setting.

1529 U.S.C. § 794 (1982 \& Supp. III 1985).

18 All states except New Mexico receive federal financial assistance for education. See Comment, Enforcing the Right to an "Appropriate" Education: The Education for All Handicapped Children Act of 1975, 92 HaRv. L. Rev. 1103, 1105 n.18 (1979).

4729 U.S.C. $\S 706(7)$ (B) (1982). "Major life activities" include functions such as caring for one's self, performing manual tasks, walking, seeing, hearing, breathing, learning, and working. 45 C.F.R. $\$ 84.4(\mathrm{j})(2)$ (ii) (1985).

18 See 45 G.F.R. $\& 84.4(\mathrm{~g})(2)$ (iv) (1985). 
case law interpreting it indicate that individuals with contagious diseases are included within the Act's coverage. Although AIDS cannot be transmitted by casual contact, it is among the contagious diseases addressed by the Act. In fact, the Act prohibits public schools that receive federal aid from discriminating not only against children who have been diagnosed as having AIDS, but also against children who are perceived by the public or by school administrators as being AIDS victims.

Children diagnosed as having AIDS fall within the purview of the Act. An AIDS patient does indeed suffer from a "physical . . . impairment which substantially limits one or more of such person's major life activities." 49 The regulations promulgated under the Act define "physical or mental impairment" to mean, among other things, any physiological condition affecting the lymphatic system. ${ }^{60}$ Because AIDS interferes with the body's ability to produce certain leucocytes, which comprise part of the lymphatic system, children diagnosed as having AIDS have a "physical impairment" within the scope of the Act. ${ }^{51}$ AIDS-linked children who have not been diagnosed as having the dis-

429 U.S.C. $\S 706(7)$ (B) (1982).

${ }^{80}$ See 34 C.F.R. \$ 104.3(j)(2)(i)(A) (1986).

${ }^{\text {B1 See }} 45$ C.F.R. § 84.4(j)(2)(iii) (1985); see also District 27 Community School Bd. v. Board of Educ., 130 Misc. 2d 398, 415, 502 N.Y.S.2d 325, 336 (Sup. Ct. 1986) (discussing application of the Act to children with AIDS).

For a thorough discussion of the language of the Act and a survey of corresponding state statutes in the context of employment discrimination, see Leonard, Employment Discrimination Against Persons with AIDS, 10 U. DAYTON L. Rev. 681, 689-96 (1985). Leonard asserts that AIDS is an "impairment" within the meaning of the Act: the disease "impairs the 'essential life function' of the immune system, limiting the ability of the body to fight infection and preserve health, and causing physical debilitation that affects strength and endurance." Id. at 696.

Leonard also discusses several state statutes that specifically classify a disease or illness as a handicap in the same manner that a genetic defect or an injury would be considered a handicap. Id. at 692, 695. An illustration of this sort of classification appears in New York state law, which defines "physically handicapped children" as those "who are handicapped by reason of a defect or disability, whether congenital or acquired by injury, or disease, or who are suffering from long-term disease." N.Y. PUB. HEALTH LAW § 2581 (McKinney 1985).

In fact, the majority of states classify AIDS as a handicap, in contrast to the Department of Justice, which permits an employer to refuse to hire persons with AIDS if the employer cites " "fear of contagion, whether reasonable or not." " N.Y. Times, Sept. 17, 1986, at A20, col. 1. A Justice Department memorandum regarding the application of $\S 504$ to AIDS-linked persons concludes that "an individual's (real or perceived) ability to transmit the disease to others is not a handicap within the meaning of the statute" and, therefore, that "discrimination on this basis does not fall within section 504." Office of Legal Counsel, U.S. Dep't OF Justice, Application of Section 504 of the Rehabilitation Act to Persons with AIDS, AIDS-Related COMPLEX, OR INFECTION WITH THE AIDS VIRUS 1 (1986) (on file with the University of Pennsylvania Law Review). If the memorandum's conclusion is correct, an employer, without violating the Act, may fire an employee solely out of fear that the individual may transmit AIDS, regardless of whether any factual support exists for such a belief. 
ease are protected by the Act as well, because they are "regarded as having . . . an impairment."32

The underlying policy of the Act is to ensure that individuals with actual or perceived disabilities will not be prevented from performing activities that they are capable of performing, simply because of discriminatory views that "unfairly ignore their individual qualifications and [are] based on prejudicial beliefs about [that] class [of persons]. ${ }^{.153}$ The spirit of the Act certainly would be violated if AIDS-linked children were summarily barred from the regular classroom, rather than judged on the basis of their present ability of an AIDS-linked child to benefit from a normal education.

Furthermore, section 84.34 of the regulations promulgated under the Act provides that a recipient of federal financial assistance should offer education to a handicapped person in the least restrictive setting possible. ${ }^{54}$ In other words, the state should provide an education to handicapped persons in a setting with nonhandicapped individuals whenever feasible. ${ }^{\mathrm{ss}}$ In accordance with this principle, AIDS-linked children must not be excluded from receiving an education in the same classroom with their peers. Indeed, to exclude these children from a state program that is normally available to all children is, in effect, a quarantine. An executive order concerning quarantines identifies certain easily communicable diseases, among which neither AIDS nor any of the opportunistic diseases associated with AIDS appears. ${ }^{\text {.6 }}$ Clearly, AIDS does not pose the kind of threat that warrants quarantine from society. ${ }^{.57}$

Section 504 of the Act imposes a rebuttable presumption of illegality upon any defendant who bars handicapped children from their reg-

32 29 U.S.C. $\$ 706(7)(B)(1982)$.

ss Leonard, supra note 51, at 696.

o4 See 45 C.F.R. \& 84.34 (1985).

ss The same philosophy appears in the Education of the Handicapped Act, 20 U.S.C. $§ \S 1400-1454$ (1982 \& Supp. III 1985), and is known as "mainstreaming." The Education of the Handicapped Act will be discussed subsequently, see infra text accompanying notes $92-110$.

${ }^{86}$ See Exec. Order No. 12,452, 48 Fed. Reg. 56, 927 reprinted in 42 U.S.C. § 264 (Supp. III 1985). The list of "quarantinable communicable diseases" includes "Cholera or suspected Cholera, Diphtheria, infectious Tuberculosis, Plague, suspected Smallpox, Yellow Fever, and suspected Viral Hemorrhagic Fevers.” Id. Included in the list of opportunistic diseases that the CDC considers indicative of the presence of AIDS are: disseminated histoplasmosis, isosporiasis, bronchial or pulmonary condiasis, nonHodgkin's lymphoma of high-grade pathologic type and of B-cell of unknown immunologic phenotype, Kaposi's sarcoma, and, unless tests for the HTLV-III virus are negative, chronic lymphoid interstitial pneumonitis. Indiana St. Bd. of Health, supra note 11 , at 7 .

s7 See supra notes 25-32 and accompanying text. 
ular classrooms. ${ }^{58}$ Since the real or perceived handicaps of AIDS-linked children are totally unrelated to their potential for successful performance in school, a segregated AIDS child needs only to establish a prima facie case of discrimination. ${ }^{69}$ At that point, the school board that separated the child would have to present evidence to rebut the claim of discrimination. If it could not, it would then have to integrate the child..$^{60}$

Existing case law offers limited guidance regarding the rights of AIDS victims under the Act. ${ }^{61}$ To analyze properly the issues involved

s8 See 29 U.S.C. § 794 (1982 \& Supp. III 1985); see also New York Ass'n for Retarded Children v. Carey, 612 F.2d 644, 649 (2d Cir. 1979) (construing $\S 504$ of the Act as creating a rebuttable presumption).

59 In order to present a prima facie case of discrimination, the plaintiff must demonstrate that the defendant, by having received federal financial assistance, is subject to the mandates of $\S 504$, that the plaintiff is handicapped, and that the defendant has segregated the plaintiff from the normal classroom. See Goodwin, supra note 9, at 291.

60 See Carey, 612 F.2d at 649; see also Goodwin, supra note 9, at 289. Goodwin suggests that $\S 504$ allows the plaintiff an easier case than does the Education of the Handicapped Act, because the latter legislation requires that the AIDS child "prove both the existence of segregation and the feasibility of education in an integrated setting." Id.

61 A Lexis search on January 10, 1987 using the search command "acquired immunodeficiency syndrome or acquired immune deficiency syndrome" revealed 27 cases in both federal and state courts: Fenton v. City of Philadelphia, Civ. Action No. 863529 (E.D. Pa. Sept. 22, 1986) (LEXIS, Genfed library, Courts file) (refusing to dismiss $\S 1983$ claim of sex crimes when arrestee accused by police officers of having AIDS); American Council of Life Ins. v. District of Columbia, 645 F. Supp. 84 (D.D.C. 1986) (upholding ordinance prohibiting health, life, and disability insurers from discriminating on the basis of AIDS testing); Torres v. City of Philadelphia Police Dep't Sex Crimes Unit, Civ. Action Nos. 86-3826, 86-3827 (E.D. Pa. Sept. 19, 1986) (LEXIS, Genfed library, Courts file) (dismissing, for lack of specificity, claim that police officers intimidated arrestee by telling him he might have AIDS); Broadway Books v. Roberts, 642 F. Supp. 486 (E.D. Tenn. 1986) (sustaining an ordinance regulating adult theaters, inter alia, on substantial governmental interest in preventing AIDS); Storms v. Department of Correctional Servs., No. 85 Giv. 7186 (S.D.N.Y. Apr. 18, 1986) (LEXIS, Genfed library, Courts file) (dismissing due process claim of prison legal assistant representing prisoners with AIDS); Foy v. Owens, No. 85-6909 (E.D. Pa. Mar. 19, 1986) (LEXIS, Genfed library, Courts file) (dismissing prisoner's claims that potential AIDS carriers should be quarantined); Powell v. Department of Corrections, Nos. 85-C-820-C, 85-C-816-B (N.D. Okla. Feb. 20, 1986) (dismissing § 1983 claim of prisoner who tested positively for exposure to AIDS and thus was segregated); First-Penn Pac. Life Ins. Co. v. Mock, No. 85 C 6432 (N.D. Ill. Feb. 10, 1986) (LEXIS, Genfed library, Courts file) (settling estate of possible AIDS victim); Georgia ex rel. Slaton v. Fleck \& Assocs., 622 F. Supp. 256 (D. Ga. 1985) (refusing removal to federal court of nuisance prosecution of nightclub allegedly frequented by AIDS carriers); Baker v. Wade, 106 F.R.D. 526 (N.D. Tex.), rev'd, 769 F.2d 289 (5th Cir. 1985), cert. denied, 106 S. Ct. 3337 (1986) (denying motion to reopen trial involving constitutional attack on sodomy statute because of new evidence concerning AIDS); Cordero v. Coughlin, 607 F. Supp. 9 (S.D.N.Y. 1984) (dismissing constitutional claims of AIDS prisoners segregated from general prison population); Institut Pasteur v. United States, $10 \mathrm{Cl}$. Ct. 304 (1986) (dismissing contract action concerning AIDSrelated patent); Flood v. Wyeth Laboratories, 183 Cal. App. 3d 1272, 228 Cal. Rptr. 
in the case of a child diagnosed as having AIDS, it is helpful to analogize to cases involving other contagious diseases in which similar issues have arisen. The application of section 504 in two recent cases, one dealing with tuberculosis and the other with hepatitis $B$, strongly supports the argument that the Act also protects AIDS patients.

In Arline v. School Board, ${ }^{62}$ the Eleventh Circuit interpreted section 504 to include coverage of a contagious disease. It held that tuberculosis constitutes a handicap within the meaning of the Rehabilitation Act. In this case, a public school teacher had been dismissed after contracting tuberculosis, an illness transmitted much more easily than AIDS and, unlike AIDS, certainly transmissible in a casual setting. The court stated that the language of the Act and its implementing regulations "in every respect supports a conclusion that persons with contagious diseases are within the coverage of section 504." ${ }^{\prime \prime 3}$ The court

700 (1986) (distinguishing proposed legislative grant of immunity to developers of AIDS vaccine from denial of immunity to manufacturer of DPT vaccine); Hyland Therapeutics v. Superior Court, 175 Cal. App. 3d 509, 220 Cal. Rptr. 590 (1985) (refusing to hold plasma manufacturers strictly liable for AIDS-related death caused by contaminated blood product); Klein v. Panic, Civ. Action No. 8721 (Del. Ch. Nov. 20, 1986) (LEXIS, States library, Omni file) (denying plaintiff's application for temporary restraining order in stock option suit of AIDS research company); South Fla. Blood Serv. v. Rasmussen, 467 So. 2d 798 (Fla. Dist. Ct. App. 1985) (quashing on privacy grounds subpoena to blood bank by AIDS victim requesting names of blood donors); In re Commitment of B.S., No. A-4365-85T5 (N.J. Super. Ct. App. Div. Nov. 5, 1986) (LEXIS, States library, Omni file) (authorizing commitment of mentally ill woman who incidentally had AIDS); Board of Educ. v. Cooperman, 209 N.J. Super. 174, 507 A.2d 253 (1986) (reversing education commissioner's order requiring school districts to admit children with AIDS pending holding of administrative hearing on the order); New Jersey v. Muessig, 198 N.J. Super. 197, 486 A.2d 924 (App. Div.), cert. denied, 101 N.J. 234, 501 A.2d 912 (1985) (noting that state prison system is equipped to handle AIDS); Albany County Dep't of Social Serv. ex rel. Sousis v, Seeberger, 112 A.D.2d 674, 492 N.Y.S.2d 182 (1985) (rejecting claim that blood test in paternity suit would increase prison guard's susceptibility to AIDS); Doe v. Coughlin, 132 Misc. 2d 709 ,

N.Y.S.2d 534 (Sup. Ct. 1986) (denying conjugal visit to prisoner with AIDS); District 27 Community School Bd. v. Board of Educ., 130 Misc. 2d 398, 502 N.Y.S.2d 325 (Sup. Ct. 1986) (holding that the Rehabilitation Act and the equal protection clause of the fourteenth amendment prevent automatic exclusion of children with AIDS from New York City schools); City of New York v. New Saint Mark's Baths, 130 Misc. 2d 911, 497 N.Y.S.2d 979 (Sup. Ct. 1986) (granting preliminary injunction to close bathhouses pursuant to state regulation aimed at preventing AIDS); Menaldino ex rel. Smyth v. Rawson, 127 Misc. 2d 931, 487 N.Y.S.2d 685 (Fam. Ct. 1985) (rejecting claim that blood test in paternity suit would increase prison guard's susceptibility to AIDS); LaRocca v. Dahlsheim, 120 Misc. 2d 697, 467 N.Y.S.2d 302 (Sup. Gt. 1983) (rejecting challenge to prison policies concerning AIDS); Feigly v. Jeffes, 501 A.2d 385 (Pa. Commw. Ct. 1986) (dismissing for deficient service of process prisoner's claim that prison food handlers should be screened for AIDS); Pawlisch v. Barry, 126 Wis. 2d 162, 376 N.W.2d 368 (Ct. App. 1985) (sustaining removal of board of health member who disagreed with county executive over AIDS policy).

62772 F.2d 759 (11th Cir. 1985), cert. granted, 106 S. Ct. 1633 (1986).

6s Id. at 764 . 
concluded that "coverage . . . clearly ... promote[s] Congress's intent to reduce instances of unthinking and unnecessary discrimination against those who are the focus of the statute's concern. . . ."64 Thus, the teacher was ordered reinstated. Clearly, AIDS patients should receive the same or greater consideration, because AIDS poses less of a threat of infection than does tuberculosis. As in Arline, the rationale of any school board choosing to segregate an AIDS child would not "reflect a well-informed judgment grounded in a careful and open-minded weighing of the risks and alternatives"; rather, the board simply would be yielding to "reflexive reactions grounded in ignorance or capitulat[ing] to public prejudice."

New York State Association for Retarded Children v. Carey ${ }^{68}$ also suggests that children diagnosed as having AIDS are protected by the Act. In Carey, the Court of Appeals for the Second Circuit overturned a decision by school administrators to segregate from their regular classrooms certain mentally retarded children infected with hepatitis B. The court based its decision solely on section 504's mandate that handicapped children should not be excluded from regular public school sessions simply because of their handicap. ${ }^{67}$

AIDS is often compared with hepatitis $\mathrm{B} .^{68}$ Like AIDS, hepatitis $B$ has no known cure and can be transmitted through sexual contact, exposure to contaminated blood or blood products, or infection in utero from a mother to her offspring. ${ }^{69}$ Hepatitis B, however, is "both har.dier and more infectious than HTLV-III/LAV,"70 and some experts believe hepatitis $B$, unlike AIDS, may be transmitted through infected saliva. ${ }^{71}$ The GDC has stated that the hepatitis B mode of transmission approximates the worst possible case scenario for the spread of AIDS, because the risk of acquiring hepatitis B is "far in excess" of the risk of contracting AIDS. ${ }^{72}$ The CDC maintains that if the precautions fol-

64 Id.

es Id. at 765 .

68 612 F.2d 644 (2d Cir. 1979).

62 See id. at 649 .

68 See, e.g., Centers for Disease Control, Summary: Recommendations for Preventing Transmission of Infection with Human T-Lymphotropic Virus Type IIII Lymphadenopathy-Associated Virus in the Workplace, 34 MORBIDITY \& MoRTALITY WEEKLY REP. 681 (1985) [hereinafter Summary]; Foege, The National Pattern of Aids, in The AIDS EPIDEMIC 15 (K. Cahill ed. 1983).

69 See Summary, supra note 68, at 682-83; see also D. Rothman \& S. RothMAN, THE WILlowBrook Wars 269 (1984) (indicating that contact with blood and other bodily fluids is the primary means of contracting hepatitis).

${ }^{70}$ Summary, supra note 68, at 681 .

71 See New York State Ass'n for Retarded Children v. Carey, 466 F. Supp. 487, 489 n.1 (E.D.N.Y. 1978), affd, 612 F.2d 644 (2d Cir. 1979).

72 Summary, supra note 68, at 683. 
lowed to prevent the spread of hepatitis B are used to prevent transmission of AIDS, exposure to an AIDS patient will pose no danger of infection to a healthy individual. ${ }^{73}$ Carey presents an excellent model for analysis of the issues involving AIDS children, the only difference being that hepatitis B is transmitted far more easily than AIDS.

Carey involved the actions of school administrators who yielded to pressure from parents of healthy children and the fear of adverse publicity. The school board had devised a plan under which some known carriers of hepatitis B would be segregated within the school from their healthy peers, thereby disrupting the normal course of the segregated children's education. ${ }^{74}$ The district court stated that the potential health risk involved in exposing these children to uninfected classmates was not clearly demonstrated to be "significant":75 the "medical evidence upon which the proposal is based is sparse and fails to demonstrate any causal relationship between the classroom setting and transmission of the virus."76 Indeed, segregating the children was "an unwarranted and unnecessarily restrictive reaction to the purely theoretical risk of transmission that the [School] Board has shown."77 The court also discussed the important role schooling plays in socializing handicapped children:

A child's chance in this society is through the educational process. A major goal of the educational process is the socialization process that takes place in the regular classroom, with the resulting capability to interact in a social way with one's peers. It is therefore imperative that every child receive an education with his or her peers insofar as it is at all possible. ...

... [P]lacement of children in abnormal environments outside of peer situations imposes additional psychological

73 See id. at 681. The New York City Board of Health, for example, has suggested precautions to guard against the theoretical risk of AIDS transmission in the school setting:

If blood comes into contact with skin, as occurs when a teacher cares for a child with a bloody nose, the skin should be washed with soap and water. As an extra precaution, the skin may be wiped with an alcohol swab.

Surfaces soiled with blood should be cleaned with soap and water followed by disinfection with rubbing alcohol or household bleach.

Bites should be washed with soap and water and then wiped with an alcohol swab. In the event of a serious bite, the principal should be notified so that any further medical treatment that is necessary may be sought.

AIDS: A SPECIAL REPORT, supra note 11 , at 21.

74 See Carey, 466 F. Supp. at 492.

76 See id. at 500.

76 Id. at 499.

77 Id. at 500 . 
and emotional handicaps upon children which, added to their existing handicaps causes them greater difficulties in future life. A child has to learn to interact in a social way with its [sic] peers and the denial of this opportunity during his minor years imposes added lifetime burdens upon a handicapped individual. ${ }^{78}$

The district court held that the segregation plan violated section 504 of the Act. ${ }^{79}$ Under the Act, the schools were obligated to provide education for the infected children in the least restrictive environment possible. ${ }^{80}$ The court emphasized that the defendant could not demonstrate even a single instance of transmission of hepatitis B within the school environment;, 81 the school board's "showing of a purely theoretical risk of spread of hepatitis B predicated upon a philosophical concept of causation is insufficient to offset the weighty countervailing educational needs of the affected children. No substantial justification for the proposed discrimination has been demonstrated, which absence compels [the] conclusion" that segregating carriers of the disease violates section 504 of the Rehabilitation Act. ${ }^{82}$

Agreeing that the school board had failed to make a "substantial showing" that segregation was warranted, ${ }^{83}$ the Second Circuit affirmed the district court's decision. The court found that the school board was unable to demonstrate any more than a "remote possibility" that the disease could be transmitted in the normal classroom setting. The merely theoretical possibility of contagion did not pose the "significant risk" necessary to justify segregation. ${ }^{84}$

There are striking parallels between the situation in Carey and that involving AIDS-linked children. If a segregation plan were implemented for AIDS-linked children, school administrators would be yielding to public pressure rather than considering medical facts, just as the school board in Carey succumbed to the desires of the parents of healthy children. As the Carey courts did not echo the public's fears, no

${ }^{78}$ Id. at 496-97 (quoting Hairston v. Drosick, 423 F. Supp. 180, 183 (S.D.W. Va. 1976)).

79 See id. at 502.

so See id. at 503.

81 See id.

82 Id. The court held that the segregation plan also violated the Education of the Handicapped Act, the equal protection clause of the Constitution, and several other laws not directly related to the issues under discussion here. The court of appeals affirmed the district court's decision solely on the ground that segregating the carriers violated the Rehabilitation Act. See New York Ass'n for Retarded Children v. Carey, 612 F.2d 644, 649 (2d Cir. 1979).

ss See Carey, 612 F.2d at 650.

84 Id. at 651 . 
court should blindly accept the public's opinion regarding AIDS. Carey stands for the proposition that the unrestricted education of a child is far more important than a "purely theoretical risk of transmission" of disease in the classroom setting.

Recently, a New York State trial court adopted the reasoning of Carey when it held that automatic exclusion of juvenile AIDS victims from the classroom violated their rights under the Act. In District 27 Community School Board v. Board of Education, ${ }^{85}$ two local school boards sought an injunction to prohibit the New York City Board of Education from admitting a child thought to have AIDS to any public school in the city. The court refused to issue injunctive relief, partly on the ground that providing the relief sought would violate the mandates of the Act. ${ }^{86}$ Because the effect of the AIDS virus on the lymphatic system qualified its victims as persons with a physical impairment, as defined in the regulations promulgated under the Act, ${ }^{87}$ both AIDS victims and, presumably, those perceived as having AIDS were entitled to the Act's protection. ${ }^{88}$ The court relied in part on the Second Circuit's decision in Carey; in fact, because "several medical experts described the hepatitis B virus as being 'far more contagious' than the AIDS virus, the failure of proof in [the instant case was] even greater than . . . in Carey . . . " 89 The petitioners were unable to establish anything beyond a "remote theoretical possibility" of transmitting the AIDS virus in a school setting. ${ }^{90}$ Thus, the Board of Education could not be enjoined from admitting AIDS-linked children to their normal classrooms.

Section 504 of the Rehabilitation Act of 1973 protects AIDSlinked children from discrimination. Another federal act, the Education of the Handicapped Act, complements the Rehabilitation Act and provides similar protection. ${ }^{\text {o1 }}$

85 130 Misc. 398, 502 N.Y.S.2d 325 (Sup. Ct. 1986).

86 See id. at $413-15,502$ N.Y.S.2d at 335-36. The court also held that the relief sought would deny to the child in question the equal protection of the laws. See id. at $416-17,502$ N.Y.S.2d at $337-38$.

${ }^{87}$ See $i d$. at 414,502 N.Y.S.2d at 335 ; see supra notes $50-52$ and accompanying text.

${ }^{88}$ See District 27, 130 Misc. 2d at 414, 502 N.Y.S.2d at 336.

89 Id. at 415,502 N.Y.S.2d at 337.

${ }^{20} \mathrm{Id}$.

91 The Supreme Court held in Smith v. Robinson, 468 U.S. 992 (1984), that a handicapped child who asserted the right to have the state provide a special education could not base his claim on the Rehabilitation Act of 1973 or the equal protection clause. The Court stated that the child's only remedy was founded on the Education of the Handicapped Act. Smith did not address the issue of a child who desired to be mainstreamed but rather was limited to a situation in which a child's choice was between two or more nonmainstreamed educational placements. For a discussion concern- 


\section{B. The Education of the Handicapped Act}

The Education of the Handicapped Act ${ }^{92}$ (EHA) was enacted to "meet the educational needs of handicapped children in order to assure equal protection of the law." school boards receiving federal funding to establish and maintain "a policy that assures all handicapped children the right to a free appropriate public education," to all handicapped children." ${ }^{\prime 9}$ Furthermore, Congress wrote into the law a strong preference for mainstreaming, requiring the states to establish

procedures to assure that to the maximum extent appropriate, handicapped children . . . are educated with children who are not handicapped, and that special classes, separate schooling, or other removal of handicapped children from the regular educational environment occurs only when the nature or severity of the handicap is such that education in regular classes . . cannot be achieved satisfactorily. ${ }^{98}$

The statute defines handicapped children as those who are "mentally retarded, hard of hearing, deaf, speech or language impaired, . . . or other health impaired children." ${ }^{\text {"97 }}$ Under the regulations that implement the statute, "other health impaired children" include those who suffer from "limited strength [or] vitality . . . due to chronic or acute health problems." ${ }^{\text {"9s }}$

Like the Rehabilitation Act, the EHA appears to include AIDSlinked children within its coverage. ${ }^{99}$ AIDS patients suffer from a

ing the dichotomy between those sections of the Education of the Handicapped Act dealing with mainstreaming versus those addressing specialized education, see Goodwin, supra note 9, at 279-84; see also Roncker v. Walter, 700 F.2d 1058 (6th Cir. 1983), cert. denied, 464 U.S. 864 (1983) (holding that the free appropriate education and integrated placement requirements are two distinct mandates of the Education of the Handicapped Act).

${ }_{92} 20$ U.S.C. $\S \S 1400-1454$ (1982 \& Supp. III 1985).

ss $I$ d. $\S 1400$.

84 Id. § 1412(1).

so Id. $\S 1412(2)(\mathrm{A})(\mathrm{i})$.

as Id. $\S 1412(5)(\mathrm{B})$. This provision is commonly referred to as the "least restrictive environment" or "mainstreaming" section. The implementing regulations of the EHA are grouped under the category heading, "least restrictive environment"; the statute itself does not include such language. See 34 C.F.R. $\$ \S 300.132,300.550-.556$ (1986).

${ }^{97} 20$ U.S.C. $\S 1401(\mathrm{a})(1)$ (1982 \& Supp. III 1985) (emphasis added).

9834 C.F.R. § $300.5(b)(7)$ (1986).

os Courts addressing the legal rights of handicapped children frequently discuss the two statutes in conjunction with each other. See, e.g., New York State Ass'n for Retarded Children v. Carey, 466 F. Supp. 487, 501 (stating that the proposed segrega- 
chronic health impairment that affects their strength and vitality. Their inability to fight off infections, however, does not automatically warrant their removal from the regular classroom setting. A decision by school administrators to separate a child who does not require removal constitutes a prima facie violation of the EHA's mainstreaming provisions. ${ }^{100}$ In addition to requiring that AIDS-linked children be mainstreamed, the EHA mandates that the state assess each disabled child individually and place her according to her particular needs, rather than treat all such children in a uniform manner. ${ }^{101}$ The procedures required under the EHA ensure that all children reviewed will be mainstreamed "to the maximum extent appropriate" for each child. ${ }^{\mathbf{1 0 2}}$

The relevant question under the EHA is whether the proposed placement of an AIDS-linked child is appropriate. If it is feasible to

tion required review under the Rehabilitation Act and the EHA), affd, 612 F.2d 644 (2d Cir. 1979).

One court has suggested that the term "handicapped child" "is more narrowly defined in the Education of the Handicapped Act than [in] the Rehabilitation Act." District 27 Community School Bd. v. Board of Educ., 130 Misc. 2d 398, 418, 502 N.Y.S.2d 325, 339 (Sup. Ct. 1986). In frustrating petitioners' efforts to enjoin AIDSlinked children from attending regular classes, the court stated that "while a child with AIDS could become handicapped as a result of deterioration in his or her condition, the evidence clearly supports the determination that such children are not handicapped . . . merely because they have AIDS/ARC or are infected with the HTLV-III/LAV virus." Id. at $418-19,502$ N.Y.S.2d at 339 (emphasis added).

While endorsing the result in District 27, this Comment rejects the court's proposed classification of AIDS-linked students under the EHA. AIDS and related diseases can cause those infected to have "limited strength [or] vitality" 34 C.F.R. \& 300.5(b)(7) (1986), at any time. Moreover, AIDS-linked children must shoulder the psychological burdens and stigma inflicted by association with AIDS even when they are outwardly healthy. Thus, this Comment argues that at any given moment, AIDS and related diseases can "adversely [affect] a child's educational performance." Id. As a result, AIDS-linked children deserve the special services, such as counseling and tutoring, that they can obtain as a result of individualized treatment under the EHA. Although it appears to appreciate the EHA's preference for mainstreaming, the District 27 court underestimates the need of AIDS-linked children to benefit from the particularized attention that complements maximization of the normal classroom experience under the EHA.

The EHA does not specifically address children who are merely perceived as having health problems, such as children who are not diagnosed as having AIDS but who suffer AIDS-related discrimination. Because the statute requires that each child be individually evaluated, these children would be found completely healthy and therefore would be mainstreamed pursuant to 20 U.S.C. $\S 1412$ (5)(B) (1982 \& Supp. III 1985).

100 See Espino v. Besteiro, 520 F. Supp. 905, 911 (S.D. Tex. 1981).

101 See 20 U.S.C. § 1401(19) (1982 \& Supp. III 1985). For example, New York City has implemented procedures for reviewing schoolchildren diagnosed as having AIDS. Each student is assessed by a panel of four people from the city's Department of Health. The panel, which consists of a pediatrician, an educator, a social worker, and a parent, bases its recommendations on the "physical, developmental, neurological and behavioral (sic) condition" of each AIDS-linked child. AIDS: A SPECIAL RePORT, supra note 11 , at $20-21$.

${ }^{102}$ U.S.C. $\S 1412(5)(B)$ (1982 \& Supp. III 1985). 
place a child in an integrated setting, then to place the child elsewhere violates the EHA. With respect to children diagnosed as having AIDS, medical evidence indicates that they pose no practical danger to other children. ${ }^{103}$ The remaining question is whether other students pose such a risk to the infected child that it is necessary to remove her from the regular classroom.

A reduced immunological ability to combat illnesses that frequently affect schoolchildren might justify the segregation of children with AIDS. Not all AIDS victims, however, face equal risks of infection. The GDG has stated: "Assessment of the risk to the immunodepressed child is best made by the child's physician who is aware of the child's immune status."104 Thus, a child who has been judged by her physician to be capable of attending school should not be prevented from doing so by a school board resolution that summarily bars all AIDS-linked children from the classroom. For infected schoolchildren who have been deemed by their physicians to be capable of attending school, the benefits of learning in a classroom with nonhandicapped peers outweigh the risks of contracting potentially harmful infections.

The stigma of being labelled as abnormal severely damages the sense of self-worth of segregated AIDS-linked children. Restricted access to socializing and learning with peers does not "represent a full educational opportunity for [a child] as it isolate[s] him and tend[s] to call undue attention to his handicap."10s A Texas district court has -noted that "[f]ull social interaction is an important part of today's educational curriculum and is even more vital to a child . . . who necessarily suffers a certain degree of isolation as a result of his handicap."106 Psychologists and educators have agreed that "face-to-face contact between students"107 plays an essential role in a proper education; indeed, appropriate schooling "consists of many elements, ranging from the desk [at which the child sits] to the child who sits next to him, and includ[es] the teacher who stands at the front of his class." ${ }^{108}$ Without all these elements, an education is surely incomplete. AIDS-linked chil-

103 See supra text accompanying notes $25-32$.

${ }^{104}$ Education and Foster Care of Children, supra note 24, at 519. Furthermore, the CDG has indicated that "[t]he risk of acquiring some infections . . . may be reduced by prompt use of specific immune globulin following a known exposure." Id.

108 Espino v. Besteiro, 520 F. Supp. 905, 909 (S.D. Tex. 1981) (evaluating the isolation within a regular classroom of a seven-year-old boy "medically diagnosed as a quadriplegic and ... confined to a wheelchair," id. at 906).

${ }_{108}$ Id. at 913.

${ }^{107}$ Crockenberg \& Bryant, Socialization: The "Implicit Curriculum" of Learning Environments, 12 J. Res. Dev. Educ. 69, 71 (1978).

${ }^{108}$ Coleman, Equality of Educational Opportunity, in THE SCHOOL IN THE SOCial Order 114 (F. Cordasco, M. Hillson, \& H. Bullock eds. 1970). 
dren must not be required to suffer the consequences of segregation. Educating these children in separate classrooms or allowing them to communicate with their teachers and classmates only by telephone clearly denies them the full benefits of a proper education. ${ }^{109}$

Furthermore, if healthy children are made to believe that AIDSlinked children are somehow unfit for social interaction and therefore must be separated from the rest, these children will learn a lesson of fear, mistrust, and intolerance that they will carry into their adult lives. School administrators may unconsciously impart to healthy children a very dangerous message about those who are different and who are not responsible for their disabling condition. After all, attitudes promoted in the classroom merely reflect the misconceptions and stereotypes of society as a whole. ${ }^{110}$ Allowing AIDS-linked children to be integrated into the regular classroom would promote for all children a greater understanding and acceptance of those with differing personal characteristics.

Under the mandates of the EHA, both children diagnosed as having AIDS and children perceived as having AIDS would be protected from arbitrary discrimination in the school setting. The EHA reveals a strong preference in favor of mainstreaming. Unless a child is deemed by her doctor to be unable to attend school, the EHA, in accordance with the underlying values served by mainstreaming disabled children, requires that the child be placed with her peers in the regular classroom.

\section{The Equal Protection Clause}

The Rehabilitation Act of 1973 and the Education of the Handicapped Act prohibit discrimination against AIDS-linked children in public schools. Federal statutes, however, do not offer the only protection for these children. This Comment argues that segregating AIDSlinked children also violates their rights under the equal protection

${ }^{108}$ See Thomas, supra note 2 , at 25.

110 Education is defined as:

the aggregate of all the processes by means of which a person develops abilities, attitudes, and other forms of behavior of positive value in the society in which [the person] lives . . . [and] the social process by which people are subjected to the influence of a selected and controlled environment (especially that of the school) so that they may attain social competence and optimum individual development.

Dictionary of Education 202 (3d ed. 1973), quoted in Myers \& Jenson, The Meaning of "Appropriate" Educational Programming Under the Education for All Handicapped Children Act, 1984 S. IL.L. U.L.J. 401, 428. Schools clearly play a critical role in shaping a child's view of society. 
clause of the fourteenth amendment. ${ }^{111}$

The equal protection clause guarantees that no state shall "deny to any person within its jurisdiction the equal protection of the laws," thereby mandating that "all persons similarly circumstanced shall be treated alike." 113 This Comment maintains that AIDS-related children and healthy children with no link to AIDS are similarly situated with regard to AIDS, because neither group can transfer the disease in the normal, unrestricted school setting. Thus, by classifying AIDS-linked children in a discriminatory manner, a resolution such as the one proposed in New York City ${ }^{114}$ denies these children their constitutional right to equal protection of the laws and burdens them with a stigmatizing classification. Whether the examining court chooses to apply strict scrutiny or an intermediate level of scrutiny to legislation barring AIDS-related children from regular classes, or whether a higher level of deference is deemed to be proper, the court should find that such legislation denies to these children equal protection of the law. ${ }^{115}$

\section{Strict Scrutiny}

In order for a court to apply strict scrutiny in reviewing a regulation that segregates AIDS-linked children from their peers, the regulation must either adversely affect a fundamental right explicitly or implicitly protected by the Constitution, or operate to the disadvantage of a discrete class of people that is a "suspect class."116 In order to with-

11 Courts generally will avoid deciding a case by constitutional interpretation where statutory grounds exist on which to base the decision. See, e.g., Spector Motor Service v. McLaughlin, 323 U.S. 101, 105 (1944). Nevertheless, an argument on behalf of AIDS-linked children segregated from the regular classroom can certainly be made with respect to the equal protection clause of the fourteenth amendment. Concededly, the chances of proving a violation of the Rehabilitation Act of 1973 or the EHA are much greater. This Comment, however, simply presents all the bases on which an antisegregation action may lie.

${ }_{112}$ U.S. CoNST. amend. XIV, § 1.

113 F.S. Royster Guano Co. v. Virginia, 253 U.S. 412, 415 (1920).

114 See supra text accompanying notes 39-40.

116 A court may choose from three levels of scrutiny in reviewing legislation alleged to violate the equal protection clause. The choice depends on the nature of the challenged legislation. If a statute affects a "suspect class" or impinges on a "fundamental right," the statute will be strictly scrutinized. If a "classification, while not facially invidious, nonetheless give[s] rise to recurring constitutional difficulties," Plyler v. Doe, 457 U.S. 202, 217 (1982), the legislation will be reviewed under an intermediate level of scrutiny. If neither strict scrutiny nor intermediate scrutiny is appropriate, the legislation will be reviewed under a rational relation standard, which accords great deference to legislative judgment. See generally G. Gunther, Cases and Materials on Constitutional Law 670-76 (10th ed. 1980) (discussing the historical development of equal protection analysis).

116 See San Antonio Indep. School Dist. v. Rodriguez, 411 U.S. 1, 16-17 (1973). 
stand strict scrutiny, the legislative body that passes such a regulation must demonstrate that the classification scheme is necessary to promote a compelling government interest, and that it is precisely and narrowly tailored to serve legitimate objectives. ${ }^{117}$

In San Antonio Independent School District $v$. Rodriguez, ${ }^{118}$ the Supreme Court ruled that education is not a fundamental right; despite its "undisputed importance," it is "not among the rights afforded explicit protection under our Federal Constitution."118 One of the two bases for applying the strict scrutiny standard to allegedly discriminatory AIDS legislation is therefore unavailable. AIDS-linked children do, however, appear to fit the definition traditionally used to describe a suspect class. This Comment argues that AIDS-linked children constitute a suspect class and government efforts to segregate them from their normal classrooms should be reviewed under a standard of strict scrutiny. ${ }^{120}$

A government regulation that classifies all AIDS-linked children so as to automatically bar them from their regular schoolrooms ${ }^{\mathbf{1 2 1}}$ fits the definition of suspectness presented by Justice Brennan in Plyler $v$. Doe. ${ }^{122}$ Such a classification

reflect $[\mathrm{s}]$ deep-seated prejudice rather than legislative rationality in pursuit of some legitimate objective. Legislation predicated on such prejudice is easily recognized as incompatible with the constitutional understanding that each person is to be judged individually and is entitled to equal justice under the law .... Legislation imposing special disabilities upon groups disfavored by virtue or circumstances beyond their control suggests the kind of "class or caste" treatment that the Fourteenth Amendment was

117 See Plyler, 457 U.S. at 217.

118411 U.S. 1 (1973).

$110 \mathrm{Id}$. at 35.

120 Although it is extremely unlikely that the Court would agree to classify AIDSlinked children as a suspect class, see infra text accompanying note 127, a discussion of the strict scrutiny standard as applied to such children is instructive nevertheless. Even if the Court refuses to classify such children as a suspect group, a finding that the children fit generally within the definition that traditionally has been used by the Court to describe a suspect class will make it more likely that the Court would categorize the children as a "quasi-suspect" class. Such categorization would require that any segregation of the class be subject to an intermediate level of review.

121 For an example of such a regulation, enacted by a community school board, see supra notes 39-40 and accompanying text.

122457 U.S. 202 (1982). Although Plyler was decided on the basis of intermediate scrutiny, Justice Brennan included in his discussion of the equal protection clause the definition of suspectness quoted in the text. 
designed to abolish. ${ }^{123}$

The government regulation described above would create stark differences between the treatment of AIDS-linked children and non-AIDSlinked children. Furthermore, AIDS-linked children would all be classified under one category, although no medical justification exists for such uniform treatment. Indeed, the only justifiable classification scheme would be one that distinguished between those children who are deemed by their physicians to be well enough to attend school, and those who are deemed to be physically unable to do so.

Such a government regulation would promote no government interest at all, much less a compelling one, as is required to withstand strict scrutiny. The medical evidence presently available indicates that there is no practical risk of transmission in the normal school setting. No government interest exists in removing, and in effect quarantining, AIDS-linked children from their normal environments. A permissible government objective of such segregation might be to protect a child diagnosed as having AIDS from contracting a potentially harmful disease from her peers in school. This objective should not be achieved, however, by simply barring all children with AIDS from the classroom. The risks of infection should be weighed separately for each AIDS patient, as the risks differ in every case.

Furthermore, automatic removal of AIDS-linked children from their normal classrooms must fail under a standard of strict scrutiny, because it is not narrowly tailored; such segregation is, in fact, fatally flawed in that it is both overinclusive and underinclusive. It is overinclusive in that it restricts AIDS-linked children entirely, because none can transmit the disease by the casual contact that occurs in the classroom. It is also overinclusive in that it bars from the classroom diagnosed AIDS patients who have been deemed by their physicians to be healthy enough to attend school. Automatic removal is underinclusive in that it fails to segregate many who in fact may be carriers of AIDS,

${ }^{123}$ Id. at 216 n.14. AIDS-linked children arguably constitute a "discrete and insular" minority, United States v. Carolene Prods. Co., 304 U.S. 144, 152 n.4 (1938). They form a clearly defined and bounded group with an "immutable" characteristic, Frontiero v. Richardson, 411 U.S. 677, 686 (1973). The disability thrust upon them as a result of their exclusion from the regular classroom is certainly harmful. Furthermore, from a political perspective, AIDS-linked children are a particularly vulnerable group: as children, they have no voting power; over half are black and almost onequarter are hispanic; most are indigent and have at least one parent infected with AIDS. Many have a parent who is an intravenous drug user. See WeEkLy SuRveILLANCE REPORT, supra note 19 , at 2 . Given these conditions, AIDS-related children seem to be in "such a position of political powerlessness as to command extraordinary protection from the majoritarian political process." Rodriguez, 411 U.S. at 28 (discussing the "traditional indicia of suspectness"). 
such as untested children who are infected with the HTLV-III virus ${ }^{\mathbf{1 2 4}}$ but are asymptomatic, or children who have been very recently contaminated with the virus and would therefore generate negative antibody test results. ${ }^{125}$ Because AIDS-linked children can be classified as a suspect group, a government regulation that automatically deprives these children of the benefits of a meaningful public education is "presumptively invidious"126 and therefore unconstitutional under the fourteenth amendment.

\section{Intermediate Scrutiny}

Although strict scrutiny seems to be an appropriate standard to apply to a government regulation that automatically bars AIDS-linked children from their regular classrooms, it is necessary to consider alternative standards, as the Court traditionally has been extremely reluctant to name any class as suspect. ${ }^{127}$ Accordingly, one must examine the other levels of scrutiny used by the Court, in order to determine whether such action would be unconstitutional at these levels as well.

The Court has applied a standard of heightened scrutiny in cases where government classifications affect neither a fundamental right nor a suspect class, but nonetheless "give rise to recurring constitutional difficulties." 128 Although strict scrutiny does not apply, any regulation examined under a standard of heightened scrutiny must serve an important government objective and must be substantially related to achieving that objective. ${ }^{129}$ Several courts of appeals and commentators have acknowledged that an intermediate level of deference has been applied to "legislative restrictions on access to education."130 The particu-

124 Although it may be possible to remedy this underinclusiveness by subjecting all schoolchildren to the HTLV-III antibody test, a mandatory blood testing program would be unwise. Since AIDS is not transmissible in the classroom, there is no need to test children. In fact, the antibody test should not be used diagnostically because it is not completely accurate and false positive readings may result. It cannot test for the presence of AIDS, nor can it predict anything about the possibility of transmitting AIDS. See AIDS: A SPECIAL REPORT, supra note 11, at 14-17. A positive test result would only cause unnecessary fear, stigmatization, and ostracism. Finally, mandatory blood testing arguably violates an individual's right to privacy. See Note, supra note 35, at $1287-89$ (criticizing mandatory blood testing programs).

${ }_{120}$ See AIDS: A SPECIAL REPORT, supra note 11 , at 17.

${ }^{226}$ Plyler v. Doe, 457 U.S. 202, 216 (1982).

127 Only classifications based on "race, alienage or national origin" have been considered suspect. City of Cleburne v. Cleburne Living Center, 105 S. Ct. 3249, 3255 (1985).

${ }_{128}$ Plyler; 457 U.S. at 217.

129 See, e.g., Craig v. Boren, 429 U.S. 190, 197 (1976). The Court invalidated an Oklahoma statute which discriminated on the basis of gender as being insubstantially related to achieving the purported governmental objective. See id. at 199-204.

${ }_{130}$ Sklar v. Byrne, 727 F.2d 633, 637 n.5 (7th Cir. 1984); Halderman v. Penn- 
lar case to which these authorities refer is Plyler $v . D o e,{ }^{131}$ which involved a Texas statute that denied a public education to "undocumented" alien children. ${ }^{132}$ Although the majority opinion referred to a framework of rational relation in its decision to strike down the statute, the Court's requirement that the statute further a "substantial state interest"133 clearly indicates that the statute was reviewed under a standard of heightened scrutiny..$^{134}$

Justice Brennan, writing for the majority, evaluated the importance of education:

Public education is not a "right" granted to individuals by the Constitution. But neither is it merely some governmental "benefit." . . . [E]ducation has a fundamental role in maintaining the fabric of our society. We cannot ignore the significant social costs borne by our Nation when select groups are denied the means to absorb the values and skills upon which our social order rests.

In addition . . . denial of education to some isolated group of children poses an affront to one of the goals of the Equal Protection Clause: the abolition of governmental barriers presenting unreasonable obstacles to advancement on the basis of individual merit. . . . The inestimable toll of that deprivation on the social, economic, intellectual, and psychological well-being of the individual, and the obstacle it poses to individual achievement, make it most difficult to reconcile the cost or the principle of a status-based denial of basic education with the framework of equality embodied in

hurst State School and Hosp., 707 F.2d 702, 709 n.7. (3d Cir. 1983) (citations omitted) (the right of parents "to direct and control the upbringing of their children without unnecessary governmental interference" is protected under "an 'intermediate' level of scrutiny"); see also Comment, Intermediate Equal Protection Scrutiny of Welfare Laws that Deny Subsistence, 132 U. PA. L. REv. 1547, 1555-60 (1984) (interpreting Plyler as implicitly holding that denial of a very important interest closely related to the exercise of constitutional rights probably triggers intermediate scrutiny).

131457 U.S. 202 (1982).

132 See id. at 205.

133 Id. at 230.

134 It is possible that the majority simply would have preferred to have stated explicitly that education is a fundamental right. In order to obtain Justice Powell's vote, however, it was probably necessary to avoid such a statement; Powell had voted with the majority in San Antonio Indep. School Dist. v. Rodriguez, 411 U.S. 1 (1973), which held that education is not a fundamental right. See $i d$. at 35 . Indeed, the dissenters in Plyler asserted that the Plyler majority had applied a "quasi-suspect-class and quasi-fundamental-rights analysis." Plyler, 457 U.S. at 242, 244 (Burger, C.J., dissenting). 


\section{the Equal Protection Clause. ${ }^{135}$}

Equality of educational opportunity traditionally has been recognized as a highly important attribute of education. In Plyler, Justice Brennan addressed the complete denial of a.public education to a group of children. In contrast, the AIDS-related regulations with which this Comment is concerned do not purport to wholly deny formal learning to AIDS-linked children, as home instruction would be available for these children. ${ }^{136}$ Despite the probable contention of the school board, however, that these children would be receiving an education equivalent to that of their peers, any government regulation that automatically segregates or bars such children from their regular classrooms clearly violates the spirit of the equal protection clause. ${ }^{137}$ These children are denied a meaningful opportunity to enjoy a benefit granted to others. The exclusion operates to prevent them from ever fully assimilating into society. Isolated from other children at a young age, AIDS-linked children will feel permanently alienated from a society that has separated them from their peers.

In the absence of medical evidence that AIDS can be spread by casual contact, one important government interest, the protection of healthy children from contracting the disease, is not implicated. Another government objective, to protect AIDS-diagnosed children from contracting potentially harmful diseases in school, need not be achieved by summarily barring all such children from the schoolroom. ${ }^{138}$ Indeed,

${ }^{135}$ Plyler, 457 U.S. at $221-22$ (citations omitted).

${ }_{136}$ The resolution passed by a community school board in Queens, New York, provides that the children be educated under a program of home instruction. See Addendum, supra note 39.

${ }^{137}$ See Brown v. Board of Education, 347 U.S. 483 (1954). Although the Brown decision specifically prohibited racial segregation in public schools, the Court broadly stated:

Today, education is perhaps the most important function of state and local governments . . . [I]t is a principal instrument in awakening the child to cultural values, in preparing him for later professional training, and in helping him to adjust normally to his environment. In these days, it is doubtful that any child may reasonably be expected to succeed in life if he is denied the opportunity of an education. Such an opportunity, where the state has undertaken to provide it, is a right which must be available to all on equal terms....

We conclude that in the field of public education the doctrine of "separate but equal" has no place. Separate educational facilities are inherently unequal.

Id. at 493,495 .

${ }^{138}$ See supra text accompanying note 104. As discussed earlier, each AIDS child should be assessed individually by a physician to determine whether she may attend school. If an AIDS-linked child is deemed to be capable of attending school, govern- 
no reasonable basis exists for segregating every AIDS-linked child from the normal classroom. Under an intermediate level of scrutiny, then, the type of government regulation at issue must fail.

\section{Rationality Standard}

If a court reviewing the regulation in question considers neither strict scrutiny nor intermediate scrutiny to be the applicable standard, the regulation would be tested under the rationality standard. This standard applies to regulations that are not based upon a "suspect classification," do not affect a "fundamental right," and do not involve a "quasi-suspect" category. Under the rational relation standard, the court would determine whether the classification at issue bears a rational relation to a legitimate public purpose. ${ }^{139}$ The Supreme Court traditionally has granted considerable legislative deference to government regulations reviewed under this standard. Recently, however, the Court has demonstrated its willingness to strike down classification schemes that are not rationally related to a legitimate state purpose. ${ }^{140}$

The question with respect to AIDS-linked children is whether it is rational to treat such children differently from their peers. It is true that children diagnosed as having AIDS suffer a disability not shared by others; in the classroom setting, however, their particular disability does not warrant the distinction imposed by the government regulation at issue. Although the purpose of such regulations, the prevention of the spread of AIDS, is a legitimate end, it is not rationally served by distinguishing between AIDS-linked children and non-AIDS-linked children within the educational setting. The Supreme Court recently asserted: "The state may not rely on a classification whose relationship to an asserted goal is so attenuated as to render the distinction arbitrary or irrational."141 In the case of AIDS-linked children in the regular school setting, medical evidence clearly shows that allowing such children to remain with their peers would not pose any threat to the public's legitimate interests. A government regulation that would automati-

mental regulation that arbitrarily bars such a child from the classroom is violative of the equal protection clause.

${ }^{139}$ See City of Cleburne v. Cleburne Living Center, 105 S. Ct. 3249, 3254 (1985).

140 Last Term, the Court invalidated several laws under the rationality standard. See, e.g., id. at 3258-60 (zoning ordinance requiring a special permit to maintain a group home for the mentally retarded); Hooper v. Bernalillo County Assessor, $105 \mathrm{~S}$. Ct. 2862 (1985) (state statute granting tax exemptions only to Vietnam veterans who had resided within the state prior to a certain date); Metropolitan Life Ins. Co. v. Ward, 105 S. Ct. 1676 (1985) (law promoting state's domestic business by discriminating against foreign corporations).

${ }_{141}$ Cleburne, $105 \mathrm{~S}$. Ct. at 3258. 
cally bar them from the classroom fails to withstand equal protection review even under a rationality standard..$^{\mathbf{4 2}}$

\section{CONCLUSION}

Medical evidence currently available indicates that AIDS is transmitted only by sexual contact, the sharing of hypodermic needles, blood transfusions, and in utero infection from a mother to her offspring. There appears to be absolutely no risk of spreading the disease by casual contact, such as that which occurs in the classroom. In addition, the risk that a child diagnosed as having AIDS will contract a potentially harmful disease from her peers in school should be assessed on an individual basis. School administrators who arbitrarily segregate all AIDSlinked children from their classmates are yielding to the pressure of uninformed public fear. ${ }^{143}$ By preventing these children from obtaining the full measure of educational benefits to which they are entitled, a school board acts in violation of the Rehabilitation Act of 1973, the Education of the Handicapped Act, and the equal protection clause of the fourteenth amendment. Instead of classifying such children as a single group, proper authorities should separately assess each AIDSlinked child to determine the most appropriate educational placement for that child.

142 In Cleburne, the majority held that the mentally retarded are neither a suspect class nor a quasi-suspect class because they are not a discrete group of people, do not suffer prejudice, and are not without the political power that traditionally characterizes a suspect class. See id. at 3256-57. Also, the Court stated that it did not want to set a precedent that might hold for similar groups. See id. at 3257-58. Although the Court reviewed legislation affecting the mentally retarded under a "mere rationality" standard, it declared such legislation to be violative of the equal protection clause because no rational basis existed for the regulation in question. See id. at 3258-60.

For purposes of equal protection analysis, AIDS-linked children are situated analogously to mentally retarded persons. Thus, as discussed in the text, see supra text accompanying. notes $139-42$, if a strict scrutiny analysis or an intermediate level of deference is not used to review governmental regulation arbitrarily barring AIDSlinked children from the classroom, such regulation would certainly fail under a rationality standard of review.

A New York trial court recently asserted: "Absent any rational basis for . . . [the] proposed exclusion [from school] of only known AIDS cases or carriers of the virus, without imposing such exclusion in the case of ARC patients or asymptomatic carriers[,] . . . such a proposal must be deemed a denial of equal protection of the laws." District 27 Community School Bd. v. Board of Educ., 130 Misc. 2d 398, 416, 502 N.Y.S.2d 325, 337 (Sup. Ct. 1986).

143 Giovanni Boccaccio, describing the bubonic plague that devastated fourteenth century Europe, wrote: "The events . . . caused various fears among those people who survived, all tending to the same cruel and uncharitable end which was to avoid the sick and everything that had been near them. . . . And the public distress was such that all laws, whether human or divine, were ignored." See Finegold, Protecting Health Personnel, in The AIDS EPIDEMIC 123, 124 (K. Cahill ed. 1983). 
There is no evidence that AIDS has ever been contracted through casual contact. This society must not allow an innocent minority to be ruled by a misinformed majority. The consequences of segregating AIDS-linked children and unjustifiably granting them an inferior education "may affect their hearts and minds in a way unlikely ever to be undone."144 dissenting). 
